\title{
Equity Risk Premium: A Cross Country Analysis on Return Behaviour
}

\author{
Santhosh Kumar*
}

\begin{abstract}
The equity risk premium has been of paramount importance in the field of finance and is still a widely utilised central element for every risk return model in corporate finance, asset pricing and other fields of economic literature. This research captures the differences in the ex-post behaviour of equity risk premium between developed and emerging markets. Further, an investigation has been made into the impact of global integration on the ERP across G7 countries and 7 emerging countries. The analysis has shown a decline in the ERP of developed nations and an upward trend in emerging markets over the chosen sub-sample period. We found out that there exists low correlation in ERP of emerging markets in comparison with developed markets. Therefore the findings suggest that a rational investor, having declining absolute risk aversion, can reduce his portfolio risk by diversifying his investment across emerging markets.
\end{abstract}

Keywords: Equity risk premium; Emerging Markets; Stock market returns; Volatility; MSCI

\section{Introduction}

Investors invest in the equities for the purpose of higher return. According to the view of Amihud (2002), the risk free rate of return provides less amount of return compared to that of equities. Therefore, the investors are inclined to take the additional risks.

*Assistant Professor, Department of Economics, Christ University, Bangalore, India; santhosh.kumar@christuniversity.in 
However, the risk free rate of return is also termed as the riskless bond. The difference between the equity rate of return and the risk free rate of return is defined as Equity Risk Premium. A number of empirical observations have focussed on equity risk premiums of advanced countries, especially that of the US, rarely on the younger or emerging equity markets. Even data estimates on other equity markets like that of European equity markets have been minimal, let alone the emerging markets. For instance, data availability on the US market can date back to 1871, while market data for emerging markets are available from the 1880s only. Mehra and Prescott (1985) disclosed that the equity risk premium in the US equity market surpassed the expected risk premium of that standard theory by a large margin. According to their study, stocks should provide around $0.35 \%$ equity premium over bonds and after extending the parameter estimates they concluded with a maximum surpass of $1 \%$. However, the historical equity risk premium of the US was $6.2 \%$.The US share in the global stock market has climbed a high of around $50 \%$ in the recent years, as measured by equity market capitalisation, based on a study conducted by Stauton (2004). These factors indicate a superior performance of the US equity market, suggesting that no other market can compete with this long term accomplishment. Ibbotson estimated that the US equity risk premium was around 9.2\% from the period of 1926-1999, while Barclays Capital (1999) estimated an equity risk premium of $8.8 \%$. Relatively, there are very few studies reaching beyond the US and UK equity markets. Bernartzi (1995) suggested that that a higher ERP appeals for greater investment in the stock market. Since studies have often pointed out the average long-term ERP in the US market tends to surpass the expected levels as predicted by the equilibrium theory, investors are mostly inclined towards equity markets of developed nations. Emerging markets on the other hand, often have to face the perception of being more risky in nature, therefore being less appealing to investors as that of the advanced economies.

However, over the years, many international companies have been drawn to the promise of fast growing emerging markets that have become large and important. The capital markets of such countries have developed and are attracting investments from all over the world, including the US and other developed nations. According to 
a study conducted by Grootveld and Salmon (2003), the equity risk premium in emerging markets seemed to be much higher than that of advanced markets. They also showed the time varying nature of ERP, suggesting that rewards to investors varied through time.The cost of capital in the emerging markets has fallen considerably due to deep reforms over the years, leading to huge impacts on earnings and valuation of equities. Financial sector reforms have been applauded by improved investor access to information, earning and economic stability. Overall, these factors indicate great openings for investment in emerging markets. Yet there are still unnecessary cautions taken by investors for the additional risks they are exposed to in the emerging markets, leading to the rejection of good investment opportunities. These additional risks may include fluctuations in exchange rates, accelerated inflation, rigid laws and fiscal policies and political distress.

\section{Determinants of Equity Risk Premium}

Before we ponder disparate ways for approximating equity risk premiums, we should scrutinize the factors that ascertain equity risk premiums. The major determinants of equity risk premium are categorizes as (a) Risk Aversion and Consumption Preferences: which consists of Investor Age and Preference for current consumption (b) Economic Risk (c) Information (d) Liquidity (e) Catastrophic Risk (f) Government Policy (g) The behavioral/ irrational component.

\section{Review of Literature}

The literature for this paper was primarily sourced to be in tandem with return behaviour from a global viewpoint. The reviews in general showcase important aspects of the concept of equity risk premium and have been extensive in covering equity risk premium in the US equity markets. However, the coverage of other advanced economies has been minimal and from an empirical side, the coverage of emerging markets is of near absence.

Mehra \& Prescott (1985), even though economists had acknowledged the existence of equity risk premium, this concept drew its importance from the article "The Equity Premium: A 
Puzzle". The studied the US data from a period of 1889-1978 and found the equity risk premium to be very high, indicating a very high co-efficient of risk aversion. They argued that the models used to determine investor's behaviour were invalid or the actual returns that investors received were much higher than expected. This "puzzle" postulated by Mehra and Prescott stimulated great researches in the field of equity risk premium.

Bernartzi \& Thaler (1995), they studied the enormously discussed equity risk premium puzzle with the assumptions that investors are loss averse and are more sensitive to losses than to gains. In other words, investors have a myopic loss aversion. They claimed that a higher equity was a necessary condition for investors to invest in stock markets. Bernatzi and Thaler were in line with the findings of Mehra and Prescott and postulated that it was impossible to reconcile with the high rates of return on stocks and low risk free rates on bonds. Harvey (1995), studied why emerging markets are an arduous challenge to the asset pricing theory. He proposed that emerging market returns are most likely to be influenced by local information. There are a host of risk that investors face while investing in emerging markets including high transaction costs, information asymmetries, insider trader laws, infrequent trading and so on. According to Harvey, these risk increase the probability of the failure of standard asset pricing models when applied to emerging markets. These models are not adequate to capture the complexities involved in valuation of securities in both developed and emerging markets. Campbell (1995), provided the first comprehensive study of the average returns and volatility of 20 emerging markets. Data was sourced from more than 800 equities in eight Asian markets, six Latin American markets, one Middle-east market, two African markets and three European markets. These markets have been labelled by the World Bank as emerging ones, as a result of their low or middle income status. While empirically testing the correlation with developed market returns, the author found out that emerging market returns are not spanned by the developed market returns. As a result of this, investors can acquire increased expected returns and lower their portfolio risk. This study also investigates into the predictability of emerging markets returns by using both local and world information variables to forecast returns. He pointed out 
important differences in predictability between developed and emerging markets. Accordingly, the developed market correlation with US market return is closely linked to the degree of predictability. On the other hand, the correlation between emerging markets and US returns show no significant relationship with the degree of predictability. Further, the amount of predictability that one sees in emerging markets surpasses that of developed markets and one half of the emerging market's predictability variance can be traced to local information.

Bekaert et al (1997) studied emerging market volatility that plays an important role in the evaluation of asset allocation and direct investment decisions and in the determination of cost of capital. Equities from emerging markets can be vastly differentiated from those in developed markets. These differences include higher sample average returns, more predictable returns and higher volatility. The authors sourced the data of 20 emerging markets from IFC of the World Bank. The study was conducted for the period 1976- 1992 and the returns were based on US dollars. The total return index of each country is based on value weighted portfolio of securities. The volatility in emerging markets are characterised by very high unconditional volatility form $18 \%$ to $104 \%$, the magnitude and range of which are found to be much greater than that of developed markets. Bekaert et al discovered an increase in correlation between local market returns and world market resulting from capital market liberalisation. However, such liberalisations do not drive up local market volatility.

\section{Need for the Study}

Over the last two decades, the GDP growth rates in emerging markets have surpassed that of the developed markets, resulting in trends of infrastructure development and urbanisation. Further, the demographic profiles of most of the emerging market are inclined towards younger age ranges (30-35 years), indicating greater scope for development. This has led to huge impacts on earnings and valuation of equities. While on one hand emerging markets are said to be subjected to additional risks when compared to developed markets, empirical studies have shown that the individual risks in the former have low correlations with one and other. This study 
therefore looks primarily into the return behaviour of a number of international markets and an empirical analysis is made to capture excess returns path across world-wide equity markets. This study helps to understand the differences in the ex-post excess return's path across world markets and how it is affected by global integration. There is very little research done in the area of equity risk premium estimation, especially with respect to emerging markets. Over the last two decades, astounding globalisation has taken place, leading to elimination of obstacles to international trade and investment and huge reductions in transaction costs. This has led to transformational changes in the distributional characteristics of ERP. This research therefore captures the differences in the ex-post behaviour of equity risk premium between developed and emerging markets which will not only help investors in better decision making for investments, but also reflect upon the impact of global integration on ERP.

\section{Objectives of the Study}

- To investigate into the differences in the ex-post behaviour of equity risk premium between developed and emerging markets

- To examine the impact of global integration on ERP across 7 developed and 7 emerging markets.

\section{Data and Methodology}

The study is based on secondary panel data from January 1970 to December 2013 for a period of 43 years. The data has been analysed and compared for both the developed and the emerging markets. The monthly rate of return has been shown in the denominations of the US dollars and has been sourced from the Morgan Stanley Capital Total Return Index. The countries that has included in the study are: Australia, Canada, France, Germany, Italy, Japan, Netherlands, India, China, Russia, Indonesia and South Africa, as listed as emerging markets by the International Monetary Fund, as on, July 16, 2012.The G7 countries represent the developed markets. However, Henry (2000) argued that the proxy rate of return may not be an appropriate option for the risk free rate of return. For the 
purpose of calculating the risk premium, one month Treasury bill rate has been considered, which has been sourced from Fama and French data library.

\begin{tabular}{|l|l|}
\hline \multicolumn{1}{|c|}{ Developed Markets - G7 countries } & \multicolumn{1}{c|}{ Emerging Markets } \\
\hline United States & India \\
\hline United Kingdom & China \\
\hline Japan & South Africa \\
\hline Canada & Brazil \\
\hline France & Korea \\
\hline Germany & Malaysia \\
\hline Italy & Russia \\
\hline
\end{tabular}

\section{Data Analysis and Interpretation:}

The equity risk premium is one of the effective measurements of the cost of equity of the country. This study observes the equity risk premium's path both for G7 markets as well as emerging markets, with the former having a smaller data sample. Thus a common range of data is used for the study, starting from Jan 2000 and ending at Jan 2013. The ex-post equity risk premium for the G7 countries and the emerging markets could be demonstrated as follows:

Table 1: Equity risk premiums of Developed Markets, in context to its distributional characteristics. (Sample period: Jan 1970- Dec 2014)

\begin{tabular}{|c|c|c|c|c|c|c|c|c|}
\hline $\begin{array}{l}\hat{E} \\
\text { E } \\
\text { ठ }\end{array}$ & $\stackrel{\dot{0}}{0}$ & ॠే & 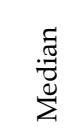 & $\begin{array}{l}\overrightarrow{\tilde{D}} \\
\text { ஸे }\end{array}$ & 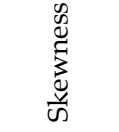 & 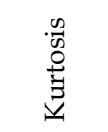 & 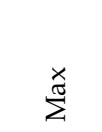 & $\stackrel{\Xi}{\Sigma}$ \\
\hline US & 528 & $0.53 \%$ & $0.33 \%$ & $4.59 \%$ & -0.54424 & 1.84478 & $16.98 \%$ & $-23.24 \%$ \\
\hline UK & 528 & $0.61 \%$ & $0.51 \%$ & $6.56 \%$ & 1.1708 & 10.9189 & $55.60 \%$ & $-23.68 \%$ \\
\hline Canada & 528 & $0.59 \%$ & $0.77 \%$ & $6.46 \%$ & -0.5487 & 5.2473 & $21.78 \%$ & $-27.18 \%$ \\
\hline France & 528 & $0.60 \%$ & $0.67 \%$ & $6.78 \%$ & -0.2960 & 1.8342 & $26.47 \%$ & $-21.24 \%$ \\
\hline Germany & 528 & $0.59 \%$ & $0.48 \%$ & $6.58 \%$ & -0.3201 & 3.8452 & $24.09 \%$ & $-24.29 \%$ \\
\hline Italy & 528 & $0.36 \%$ & $0.17 \%$ & $7.36 \%$ & 0.0214 & 2.6590 & $30.43 \%$ & $-23.67 \%$ \\
\hline Japan & 528 & $0.57 \%$ & $0.38 \%$ & $6.78 \%$ & 0.3781 & 3.1892 & $26.24 \%$ & $-19.95 \%$ \\
\hline
\end{tabular}


Table 2: Equity risk premiums of Developed Markets, in context to its distributional characteristics. (Sub-sample period: Jan 2000- Dec 2014)

\begin{tabular}{|c|c|c|c|c|c|c|c|c|}
\hline $\begin{array}{l}\hat{E} \\
\hat{\Xi} \\
\dot{0}\end{array}$ & 官 & §ँ & 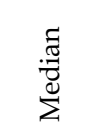 & 岂 & 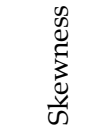 & $\begin{array}{l}\frac{n}{0} \\
0 \\
0 \\
0 \\
y\end{array}$ & $\stackrel{\stackrel{x}{a}}{\Sigma}$ & $\stackrel{\Xi}{\Sigma}$ \\
\hline US & 217 & $0.28 \%$ & $1.13 \%$ & $4.55 \%$ & -0.57562 & 0.66856 & $11.35 \%$ & $-17.23 \%$ \\
\hline UK & 217 & $0.37 \%$ & $0.39 \%$ & $4.98 \%$ & -0.36941 & 3.7136 & $14.13 \%$ & $-19.45 \%$ \\
\hline Canada & 217 & $0.93 \%$ & $1.56 \%$ & $6.64 \%$ & -0.7684 & 3.7651 & $21.68 \%$ & $-27.18 \%$ \\
\hline France & 217 & $0.32 \%$ & $0.67 \%$ & $6.62 \%$ & -0.4845 & 3.8394 & $15.89 \%$ & $-22.54 \%$ \\
\hline Germany & 217 & $0.36 \%$ & $0.71 \%$ & $7.63 \%$ & -0.4568 & 3.9764 & $23.51 \%$ & $-30.93 \%$ \\
\hline Italy & 217 & $0.23 \%$ & $0.63 \%$ & $6.78 \%$ & -0.3741 & 3.7653 & $20.53 \%$ & $-23.78 \%$ \\
\hline Japan & 217 & $-0.09 \%$ & $-0.54 \%$ & $5.63 \%$ & -0.0498 & 2.9779 & $13.56 \%$ & $-14.84 \%$ \\
\hline
\end{tabular}

Table 3: Equity risk premiums of Emerging Markets, in context to its distributional characteristics. (Sample period: Jan 1988- Dec 2014)

\begin{tabular}{|c|c|c|c|c|c|c|c|}
\hline $\begin{array}{l}\hat{E} \\
\vec{\Xi} \\
0\end{array}$ & $\begin{array}{l}\dot{0} \\
\stackrel{0}{0}\end{array}$ & 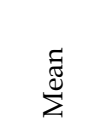 & $\begin{array}{l}\stackrel{\widetilde{\pi}}{\pi} \\
\stackrel{\Xi}{\Sigma}\end{array}$ & 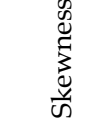 & 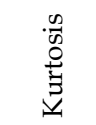 & 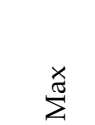 & $\Xi$ \\
\hline India & 251 & $1.26 \%$ & $1.39 \%$ & 0.1820 & 3.5822 & $36.63 \%$ & $-29.47 \%$ \\
\hline China & 251 & $0.56 \%$ & $0.58 \%$ & 0.4731 & 4.7893 & 47.48 & $-27.81 \%$ \\
\hline South Africa & 251 & $1.46 \%$ & $1.72 \%$ & -0.6178 & 4.8972 & $24.36 \%$ & $-30.94 \%$ \\
\hline Russia & 239 & $2.74 \%$ & $2.83 \%$ & 0.5341 & 3.9862 & $60.91 \%$ & $59.83 \%$ \\
\hline Korea & 311 & $1.07 \%$ & -0.54 & 1.6359 & 7.8594 & $70.76 \%$ & $-32.94 \%$ \\
\hline Malaysia & 311 & $0.89 \%$ & $0.95 \%$ & 0.6341 & 8.2948 & $49.61 \%$ & $-30.78 \%$ \\
\hline Brazil & 311 & $2.83 \%$ & $2.61 \%$ & 0.3785 & 6.9361 & $79.95 \%$ & $-68.53 \%$ \\
\hline
\end{tabular}

Table 4: Equity risk premiums of Emerging Markets, in context to its distributional characteristics. (Sub-sample period: Jan 2000- Dec 2014)

\begin{tabular}{|c|c|c|c|c|c|c|c|}
\hline $\begin{array}{l}\vec{E} \\
\Xi \\
0 \\
0\end{array}$ & $\begin{array}{l}\dot{0} \\
0 \\
0\end{array}$ & 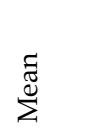 & 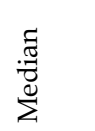 & 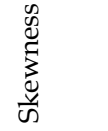 & 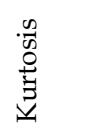 & $\stackrel{\text { }}{\sum^{\pi}}$ & $\Xi$ \\
\hline India & 217 & $1.48 \%$ & $2.42 \%$ & -0.2710 & 3.8742 & $36.63 \%$ & $-28.52 \%$ \\
\hline China & 217 & $0.96 \%$ & $1.37 \%$ & -0.4893 & 2.8491 & $19.41 \%$ & $-22.85 \%$ \\
\hline South Africa & 217 & $1.37 \%$ & $1.90 \%$ & -0.4897 & 2.8570 & $24.36 \%$ & $-26.93 \%$ \\
\hline Russia & 217 & $1.84 \%$ & $2.78 \%$ & -0.2040 & 2.7831 & $38.93 \%$ & $-35.25 \%$ \\
\hline Korea & 217 & $1.19 \%$ & $0.83 \%$ & 2.7214 & 3.1627 & $26.76 \%$ & $-27.31 \%$ \\
\hline Malaysia & 217 & $0.81 \%$ & $1.25 \%$ & -0.3961 & 2.8639 & $16.92 \%$ & $-18.35 \%$ \\
\hline Brazil & 217 & $2.04 \%$ & $2.13 \%$ & -0.4853 & 3.3383 & $28.35 \%$ & $-32.81 \%$ \\
\hline
\end{tabular}


Referring to the above scenario, it has been inferred that the volatility of the market is generally determined by the expected rate of return and the risk free rate of the return from the stock. The above table (1) and table (2) clearing depict the declining nature of ERP in developed markets. For instance, the US market has an average ERP of $0.53 \%$ in the sample period, however drops to a low $0.28 \%$ during the subsample period. On the other hand emerging markets like India for example, moves upwards from an average ERP of $1.26 \%$ in the sample period to $1.48 \%$ in the sub sample period. The declining ERP in developed markets should make investment less attractive to investors. From existing literature, it is evident that emerging markets are highly volatile. The statistics provided in the study show that such high risks are compensated by high returns in the form of higher ERP. One might argue that an investor may be risk averse in nature. However, in line with existing literature, a rational investor tends to have decreasing absolute risk aversion. To test whether ERP is normally distributed, Jaque. Bera goodness of fit test is used. The statistics are as follows:

Table 5 : J. bera Test statistics

\begin{tabular}{|l|c|c|}
\hline Countries & Sample Period & Sub-sample period \\
\hline US & 73.6548 & 8.14 \\
\hline UK & 2893.6118 & 15.18 \\
\hline Canada & 154.9812 & 30.15 \\
\hline France & 39.0163 & 7.1432 \\
\hline Germany & 41.6342 & 13.81 \\
\hline Italy & 12.8734 & 7.81 \\
\hline Japan & 13.8241 & 0.21 \\
\hline India & 4.51 & 8.15 \\
\hline China & 52.61 & 6.01 \\
\hline South Africa & 23.7132 & 5.15 \\
\hline Russia & 31.5231 & 6.14 \\
\hline Korea & 371.21 & 0.64 \\
\hline Malaysia & 370.2131 & 1.45 \\
\hline Brazil & 221.3412 & 6.53 \\
\hline
\end{tabular}

From the above table, we can see that the ERP is not normally distributed. The statistics demonstrate a negative skewness with respect to developed markets and a positive skewness with respect to emerging markets. A rational investor would prefer a positive 
skewness over a negative one and therefore, the developed markets should provide a higher ERP to investors. However, the ex-post equity analysis shows the opposite. Further, the correlation in returns of emerging markets compared to developed markets has been quite low.

\section{Conclusion}

The paper deeply captures the differences in the ex-post behaviour of equity risk premium between developed and emerging markets which would not only help investors in better decision making for investments, but also reflect upon the impact of global integration on ERP. We show a decline in the ERP of developed nations suggesting lower returns and an upward trend in the ERP of emerging markets. In line with existing literature, it is proved that emerging markets have shown higher volatility but at the same time compensate investors with high returns. Further, an investigation is made into the impact of global integration on the ERP across G7 countries and 7 emerging countries. It is seen that the ERP has increased extensively over the years on account of globalisation, suggesting higher risks undertaken by emerging markets. This study finds low correlation in ERP of emerging markets in comparison with developed markets. Further, over a period of time, a rational investor tends to show a declining absolute risk aversion. In this scenario, the findings demonstrate that the developed markets having negative skewness should compensate the investors with higher returns. However, your expost results show the exact opposite. Therefore, this study suggests that a rational investor should diversify his investments across emerging markets, thereby leading to higher returns and reduction in individual portfolio risks.

\section{References}

Bekaert, G., C. Erb, C. Harvey \& T. Viskanta, (1997), what matters for emerging equity market investments, Emerging Markets Quarterly, $17-46$.

Bekaert G. \& Harvey C. R. (1997). Emerging Equity Market Volatility. Journal of Financial Economics, 43, 29-78 
Goetzmann, W. \& Ibbotson, R. (2006). The equity risk premium. Oxford: Oxford University Press.

Harvey C. R. (1995). Predictable Risk and Returns in Emerging Markets. Re-view of Financial Studies, 8, 773-816.

Henry, P. (2000), Stock Market Liberalization, Economic Reform and Emerging Market Equity Prices. Journal of Finance, 55 (2), 529-564.

Jagannathan, R., McGrattan, E. R. \& Scherbina, A. (2000), The Declining U.S. Equity Premium. Federal Reserve Bank of Minneapolis Quarterly Review, 24 (4), 3-19.

Kocherlakota, N. R. (2009), The Equity Premium: It's Still a Puzzle, Journal of Economic Literature, 34, 42-71.

Mehra, R. \& Prescott E. C. (1985). The Equity Premium: A Puzzle. Journal Monetary Economics, 15(2), 145-161.

Mishra, D. R.,\& O'Brien, T. J., (2005). Risk and ex ante cost of equity estimates of emerging market firms. Emerging Markets Review, 6, 107-120.

Salomons, R. \& Grootveld, H. (2003), The Equity Risk Premium: Emerging vs. Developed Markets, Emerging Markets Review, 4(2), 121-144. 